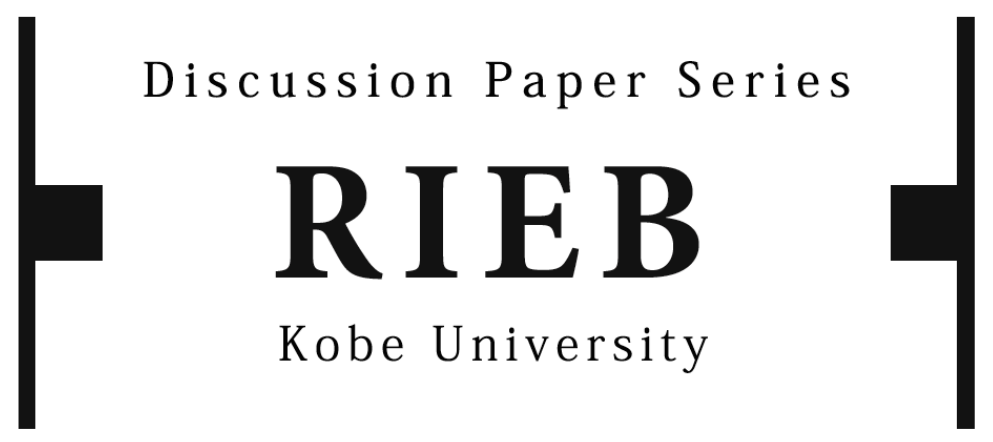

DP2015-10

\title{
Capital Controls, Monetary Policy, and Balance Sheets in a Small Open Economy
}

Shigeto KITANO

Kenya TAKAKU

Revised October 24, 2017

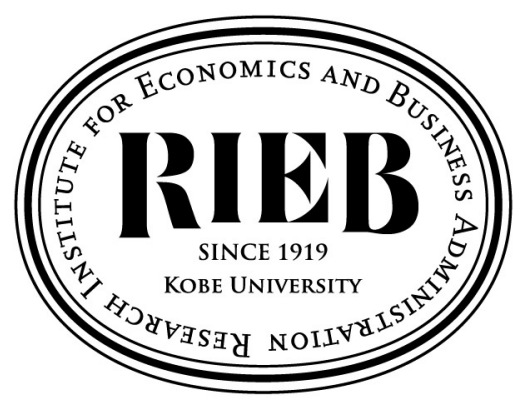

Research Institute for Economics and Business Administration Kobe University 


\title{
Capital Controls, Monetary Policy, and Balance Sheets in a Small Open Economy*
}

\author{
Shigeto Kitano ${ }^{\dagger} \quad$ Kenya Takaku ${ }^{\ddagger}$
}

\begin{abstract}
We develop a small open economy, New Keynesian model that incorporates a financial accelerator in combination with liability dollarization. Applying a Ramsey-type analysis, we compare the welfare implications of an optimal monetary policy under flexible exchange rates and an optimal capital control policy under fixed exchange rates. In an economy without the financial accelerator, an optimal monetary policy under flexible exchange rates is superior to an optimal capital control policy under fixed exchange rates. In contrast, in an economy with the financial accelerator, an optimal capital control under fixed exchange rates yields higher welfare than an optimal monetary policy under flexible exchange rates.
\end{abstract}

Keywords: capital control; monetary policy; balance sheets; Ramsey policy; exchange rate regimes; small open economy; nominal rigidities; New Keynesian; DSGE; welfare comparison; incomplete markets; financial accelerator; financial frictions.

JEL Classification: E44, E52, F32, F38, F41.

*Earlier versions of the paper were presented at the 9th Annual MIFN Conference, the SWET 2015 at Otaru University, the JEA annual meeting at Niigata University, and the 11th Annual APEA Conference at National Taiwan University. We are grateful to the referee and the co-editor William Branch for their helpful comments that have improved the paper. We are especially grateful to Mark Spiegel, Tomohiro Hirano, Kosuke Aoki, Yongseung Jung, Ippei Fujiwara, and Shin-ichi Fukuda for their valuable comments. All remaining errors are ours. This work was supported by KAKENHI (15H05729, 16K03741).

${ }^{\dagger}$ Professor, RIEB, Kobe University, 2-1, Rokkodai, Nada, Kobe, 657-8501 Japan, E-mail: kitano@rieb.kobe-u.ac.jp.

${ }_{\ddagger}^{\ddagger}$ Associate Professor, Faculty of International Studies, Hiroshima City University, 3-41, Ozuka-Higashi, Asa-Minami-Ku, Hiroshima, 731-3194, Japan, E-mail: takaku@hiroshimacu.ac.jp 


\section{Introduction}

Although capital controls are not a new policy instrument, it is not until the recent global financial crisis that the potential effects of capital control policies have been rigorously examined from the theoretical perspective as one of the most important topics in international finance. ${ }^{1}$ Given the recent financial crisis, volatile international capital movements in emerging market economies have been the subject of rigorous discussion among concerned policymakers and economists. Volatile capital flows amplify boom-bust cycles and destabilize emerging market economies. The recent global financial crisis led to a reconsideration of the merits of capital account restrictions. An increasing number of policymakers believe that capital controls can effectively stabilize economies against volatile capital flows. In fact, some emerging market countries have recently responded to instability by imposing capital controls. $^{2}$ As well known, even the IMF, a former critic of capital controls, has been forced to reconsider such measures as an important policy response to volatile capital flows under certain circumstances. ${ }^{3}$

Against this background, there has emerged a rapidly growing body of literature related to capital controls. ${ }^{4}$ Jeanne and Korinek (2010) and Bianchi (2011) show that there are pecuniary externalities associated with financial crises and provide a rationale for prudential capital controls. Using a two-country model,

\footnotetext{
${ }^{1}$ An exception is Kitano (2004). Kitano (2004) shows that capital controls not only stem the capital inflow but also reverse the associated macroeconomic effects, and are effective measures against the capital inflow problem.

${ }^{2}$ For details, see, for example, Jongwanich and Kohpaiboon (2012), Ahmed and Zlate (2014), Forbes et al. (2016), and Ghosh et al. (2017).

${ }^{3}$ For details on the IMF position, see Ostry et al. (2010) and Ostry et al. (2012).

${ }^{4}$ For details, see, for example, Korinek (2011) or Jeanne et al. (2012). For the earlier literature on capital controls, see the introduction in Kitano (2011). Kitano (2011) shows that there exists an optimal degree of capital-account restriction that achieves a higher level of welfare than that under perfect capital mobility, if the economy has costly financial intermediaries.
} 
Brunnermeier and Sannikov (2014) show that pecuniary externalities can lead to constrained inefficient outcomes and capital controls can be welfare improving. ${ }^{5}$

In recent years, an increasing number of studies examine the effects of capital controls as a regular instrument of economic policy from a broader perspective (e.g., Schmitt-Grohé and Uribe (2016), Farhi and Werning (2012), De Paoli and Lipinska (2013), and Kitano and Takaku (2017c)). ${ }^{6}$ For example, Kitano and Takaku (2017a) show that as the degree of financial frictions between banks and foreign creditors increases, more aggressive capital controls are appropriate.

Another strand of the literature focuses the relationship between capital controls and various types of monetary policies (Davis and Presno (2014), Liu and Spiegel (2015), Chang et al. (2015), and Agénor and Jia (2015)). For example, Kitano and Takaku (2017b) show that capital controls can play an alternative role to the direct credit policy in mitigating the contraction after a crisis.

Our paper is most closely related to De Paoli and Lipinska (2013), Davis and Presno (2014), and Liu and Spiegel (2015) in that we too apply a Ramsey-type analysis for capital controls. However, we examine optimal capital controls in models that highlight balance sheet effects in the presence of liability dollarization. ${ }^{8}$ Therefore, our paper is also rather closely related to Céspedes et al. (2004),

\footnotetext{
${ }^{5}$ Benigno et al. (2013) consider both ex-ante and ex-post policies in a model with pecuniary externalities. They show that the design of ex-ante policies depends on that of ex-post policies.

${ }^{6}$ Ostry et al. (2010) argue that the use of capital controls is justified under limited circumstances. Jeanne et al. (2012) go further, arguing that "[p]roperly designed capital controls may even be effective as a regular instrument of economic policy" (p.110).

${ }^{7}$ Kitano and Takaku (2017c) incorporate a banking sector with balance sheet frictions into a model of a small open economy and compare the effectiveness of capital controls and macroprudential regulation.

${ }^{8}$ Emerging economies have difficulty in borrowing abroad in their own currencies, and face a mismatch in the currency denomination of their liabilities and assets. Eichengreen and Hausmann (1999) refer to this incompleteness in financial markets as "original sin." Eichengreen and Hausmann (2005) also argue that "[w]hile the quality of institutions and policies varies enormously among developing countries, the extent of original sin does not"(page 6) and that "the
} 
Devereux et al. (2006), and Elekdağ and Tchakarov (2007). Building upon the framework developed by Bernanke et al. (1999), Céspedes et al. (2004), Devereux et al. (2006), and Elekdă̆ and Tchakarov (2007) incorporate a financial accelerator coupled with liability dollarization, in which foreign debt is denominated in foreign currency (not domestic currency). In these models, the financial accelerator works through an endogenous risk premium that is linked to the balance sheets of entrepreneurs. These balance sheets are also vulnerable to exchange rate fluctuations owing to the problem of liability dollarization.

Céspedes et al. (2004) and Devereux et al. (2006) find that the conventional wisdom, that the flexible exchange rate is preferable to the fixed exchange rate, holds in spite of the financial accelerator effects. Elekda $\breve{g}$ and Tchakarov (2007) also confirm that the flexible exchange rate regime has better welfare properties than the fixed exchange rate regime when the country has perfect access to international capital markets. However, when their model incorporates a financial accelerator and the leverage ratio exceeds a threshold, they find that the fixed exchange rate regime could become welfare superior.

We develop a small open economy, New Keynesian model with and without a financial accelerator mechanism, the model structure of which is basically similar to Céspedes et al. (2004), Devereux et al. (2006), and Elekdağ and Tchakarov (2007). We then apply a Ramsey-type analysis and examine the welfare implications of capital control policies.

In the case without the financial accelerator, we compare three cases: optimal monetary policy under flexible exchange rates, optimal capital control policy (on

difficulty emerging markets experience in attempting to borrow abroad in their own currencies has something to do with the structure of the international system" (page 6). 
households) under fixed exchange rates, and fixed exchange rates (without capital controls). Our Ramsey-type analysis results indicate that although the optimal capital control policy significantly improves welfare under fixed exchange rates, the optimal monetary policy is the most welfare-maximizing in an economy without the financial accelerator.

In the case with the financial accelerator, we compare the following five cases: an optimal monetary policy under flexible exchange rates, fixed exchange rates (without capital controls), an optimal capital control policy on entrepreneurs, an optimal capital control policy on households, and an optimal capital control policy on both entrepreneurs and households under fixed exchange rates. Our analysis results indicate that the optimal monetary policy still outperforms the optimal capital control policy on households. However, the optimal capital control policy on entrepreneurs outperforms the optimal monetary policy. The most welfaremaximizing is the optimal capital control policy on both entrepreneurs and households.

The intuition underlying our analysis results is straightforward. Entrepreneurs finance investment partly with foreign borrowing, which is subject to financial frictions in the presence of balance sheet vulnerabilities. In an economy with a financial accelerator, the key variable is the foreign interest rate augmented by an external finance premium. Monetary policy works only through domestic interest rates. However, capital controls on entrepreneurs have a direct control on the key variable of interest rates at which entrepreneurs borrow abroad. Therefore, capital controls can be welfare improving in an economy with financial frictions.

The remainder of the paper is organized as follows. In Section 2, we present a sticky price, small open economy model with and without a financial accelerator 
in combination with liability dollarization. In Section 3, we perform a comparative analysis of welfare for alternative policy regimes in this economy. For the economy without the financial accelerator, we compare (i) the flexible exchange rate regime accompanied by an optimal monetary policy, (ii) the fixed exchange rate regime accompanied by optimal capital controls on households, and (iii) the fixed exchange rate regime (without capital controls). For the economy with the financial accelerator, we compare (i) the fixed exchange rate regime accompanied by optimal capital controls on households and entrepreneurs, (ii) the fixed exchange rate regime accompanied by optimal capital controls on entrepreneurs, (iii) the flexible exchange rate regime accompanied by an optimal monetary policy, (iv) the fixed exchange rate regime accompanied by optimal capital controls on households, and (v) the fixed exchange rate regime (without capital controls). In Section 4, we check the robustness of our results. In the previous section, we show the welfare rankings for three shocks together: productivity shock, export shock, and foreign interest rate shock. In this section, we show that our results are robust even when we consider these shocks individually. Conclusions are presented in Section 5.

\section{Model}

We employ the small open economy structure developed by Galí and Monacelli (2005) and Faia and Monacelli (2008). The small open economy model incorporates a financial accelerator a la Bernanke et al. (1999) in combination with liability dollarization. Our model is close to those in Céspedes et al. (2004), Devereux et al. (2006), and Elekdağ and Tchakarov (2007). The small open economy consists of households, production firms, entrepreneurs, and the government. 


\subsection{Households}

A representative household maximizes its expected lifetime utility:

$$
E_{0} \sum_{t=0}^{\infty} \beta^{t}\left\{\frac{C_{t}^{1-\sigma}}{1-\sigma}-\frac{L_{t}^{1+\phi}}{1+\phi}\right\}
$$

where $E_{t}$ denotes the mathematical expectations operator conditional on information available at time $t, \beta \in(0,1)$ is the discount factor, $C_{t}$ signifies a composite consumption index, and $L_{t}$ represents labor effort. Households consume differentiated goods (produced by both domestic and foreign firms). The composite consumption index $C_{t}$ is given by

$$
C_{t} \equiv\left[(1-\gamma)^{\frac{1}{\eta}} C_{H, t}^{\frac{\eta-1}{\eta}}+\gamma^{\frac{1}{\eta}} C_{F, t}^{\frac{\eta-1}{\eta}}\right]^{\frac{\eta}{\eta-1}}
$$

$\eta(>0)$ is the elasticity of substitution between domestic and foreign goods, and $\gamma \in(0,1)$ represents the measure of openness. $C_{H, t}$ and $C_{F, t}$ are, respectively, the indices for consumption of domestic and foreign goods, expressed by

$$
C_{H, t} \equiv\left[\int_{0}^{1} C_{H, t}(j)^{\frac{\varepsilon-1}{\varepsilon}} d j\right]^{\frac{\varepsilon}{\varepsilon-1}} ; \quad C_{F, t} \equiv\left[\int_{0}^{1} C_{F, t}(j)^{\frac{\varepsilon-1}{\varepsilon}} d j\right]^{\frac{\varepsilon}{\varepsilon-1}}
$$

where $\varepsilon(>1)$ is the parameter for the elasticity of substitution among differentiated goods. A household's optimal expenditure allocation in each goods category yields the demand functions for domestic and foreign differentiated goods:

$$
C_{H, t}(j)=\left(\frac{P_{H, t}(j)}{P_{H, t}}\right)^{-\varepsilon} C_{H, t} ; \quad C_{F, t}(j)=\left(\frac{P_{F, t}(j)}{P_{F, t}}\right)^{-\varepsilon} C_{F, t},
$$


where $P_{H, t}(j)$ and $P_{F, t}(j)$ denote the domestic-currency-denominated prices of differentiated goods $j$ produced by domestic and foreign firms, respectively. $P_{H, t}$ and $P_{F, t}$ are the domestic and import price indices, respectively:

$$
P_{H, t} \equiv\left[\int_{0}^{1} P_{H, t}(j)^{1-\varepsilon} d j\right]^{\frac{1}{1-\varepsilon}} ; \quad P_{F, t} \equiv\left[\int_{0}^{1} P_{F, t}(j)^{1-\varepsilon} d j\right]^{\frac{1}{1-\varepsilon}} .
$$

From Eq. (5), we obtain

$$
\int_{0}^{1} P_{H, t}(j) C_{H, t}(j) d j=P_{H, t} C_{H, t} ; \quad \int_{0}^{1} P_{F, t}(j) C_{F, t}(j) d j=P_{F, t} C_{F, t} .
$$

The optimal expenditure allocation between domestic and imported goods gives

$$
C_{H, t}=(1-\gamma)\left(\frac{P_{H, t}}{P_{t}}\right)^{-\eta} C_{t} ; \quad C_{F, t}=\gamma\left(\frac{P_{F, t}}{P_{t}}\right)^{-\eta} C_{t}
$$

where $P_{t}$ represents the consumer price index $(\mathrm{CPI})$ :

$$
P_{t} \equiv\left[(1-\gamma) P_{H, t}^{1-\eta}+\gamma P_{F, t}^{1-\eta}\right]^{\frac{1}{1-\eta}}
$$

From Eqs. (7) and (8), we obtain

$$
P_{H, t} C_{H, t}+P_{F, t} C_{F, t}=P_{t} C_{t} .
$$

Households have access to domestic and international financial markets. A 
household's budget constraint in period $t$ is given as

$P_{t} C_{t}+\left(1+i_{t-1}\right) A_{t-1}+\left(1+\tau_{h, t-1}\right)\left(1+i_{t-1}^{*}\right) \mathcal{E}_{t} B_{t-1}+P_{t} \frac{\psi_{B}}{2}\left(B_{t}-B\right)^{2}=A_{t}+\mathcal{E}_{t} B_{t}+W_{t} L_{t}+T_{h, t}+\Pi_{t}^{F}$

Herein, $A_{t}$ is the domestic currency debt position, $B_{t}$ is the foreign currency debt position, $i_{t}$ is the interest rate of domestic currency assets, $i_{t}^{*}$ is the interest rate of foreign currency assets, and $\mathcal{E}_{t}$ is the nominal exchange rate (in terms of the domestic currency). ${ }^{9} W_{t}$ is the nominal wage, $\Pi_{t}^{F}$ is dividends from firms, $\tau_{h, t}$ is the tax on the foreign currency debt of households, and $T_{h, t}$ is the lump-sum transfer. $P_{t} \psi_{B}\left(B_{t}-B\right)^{2} / 2$ is the portfolio adjustment costs, which induce the stationarity of the equilibrium dynamics in the small open economy. ${ }^{10}$

The households' optimality conditions are given by

$$
\begin{gathered}
\lambda_{t}^{h}=C_{t}^{-\sigma}, \\
\lambda_{t}^{h}=\frac{L_{t}^{\phi}}{W_{t} / P_{t}}, \\
1=\beta\left(1+i_{t}\right) E_{t}\left\{\frac{\lambda_{t+1}^{h}}{\lambda_{t}^{h}} \frac{P_{t}}{P_{t+1}}\right\},
\end{gathered}
$$

\footnotetext{
${ }^{9}$ The position of the domestic asset $A_{t}$ turns out to be zero in equilibrium in our model. However, the inclusion of the domestic asset $A_{t}$ enables us to introduce the domestic interest rate $i_{t}$ into the model as in Eq.(10). Following Devereux et al. (2006) and Elekdağ and Tchakarov (2007), we therefore include the domestic asset $A_{t}$ so that we can analyze the effect of monetary policy of changing the domestic interest rate $i_{t}$.

${ }^{10}$ The small open economy model with incomplete asset markets features equilibrium dynamics that possess a random walk component (Schmitt-Grohé and Uribe (2003)). To yield stationarity of the equilibrium dynamics in a small open economy, Neumeyer and Perri (2005) use a model with convex portfolio adjustment costs. The portfolio adjustment cost is often used for "closing" a small open economy. Schmitt-Grohé and Uribe (2003) present alternative approaches to induce stationarity.
} 
and

$$
1=\beta\left(1+\tau_{h, t}\right)\left(1+i_{t}^{*}\right)\left[1-\frac{\psi_{B} P_{t}\left(B_{t}-B\right)}{\mathcal{E}_{t}}\right]^{-1} E_{t}\left\{\frac{\lambda_{t+1}^{h}}{\lambda_{t}^{h}} \frac{P_{t}}{P_{t+1}} \frac{\mathcal{E}_{t+1}}{\mathcal{E}_{t}}\right\}
$$

Combining (13) and (14) yields the interest parity condition:

$$
\left(1+i_{t}\right) E_{t}\left\{\frac{\lambda_{t+1}^{h}}{\lambda_{t}^{h}} \frac{P_{t}}{P_{t+1}}\right\}=\left(1+\tau_{h, t}\right)\left(1+i_{t}^{*}\right)\left[1-\frac{\psi_{B} P_{t}\left(B_{t}-B\right)}{\mathcal{E}_{t}}\right]^{-1} E_{t}\left\{\frac{\lambda_{t+1}^{h}}{\lambda_{t}^{h}} \frac{P_{t}}{P_{t+1}} \frac{\mathcal{E}_{t+1}}{\mathcal{E}_{t}}\right\}
$$

Since we assume that the law of one price holds for individual goods, the terms of trade are given as

$$
S_{t} \equiv \frac{P_{F, t}}{P_{H, t}}=\frac{\mathcal{E}_{t} P_{t}^{*}}{P_{H, t}}
$$

where $P_{t}^{*}$ denotes the CPI in the foreign country (in terms of foreign currency). ${ }^{11}$ It follows from (16) that

$$
\frac{S_{t}}{S_{t-1}}=\frac{\Delta \mathcal{E}_{t}}{\Pi_{H, t}}
$$

where $\Delta \mathcal{E}_{t}\left(\equiv \frac{\mathcal{E}_{t}}{\mathcal{E}_{t-1}}\right)$ and $\Pi_{H, t}\left(\equiv \frac{P_{H, t}}{P_{H, t-1}}\right)$ denote the depreciation rate of the nominal exchange rate and the rate of domestic inflation, respectively. It follows from CPI (8) and (16) that

$$
\frac{P_{t}}{P_{H, t}}=\left[(1-\gamma)+\gamma S_{t}^{1-\eta}\right]^{\frac{1}{1-\eta}} \equiv g\left(S_{t}\right)
$$

From (18), CPI inflation $\Pi_{t}\left(\equiv \frac{P_{t}}{P_{t-1}}\right)$ is expressed as

$$
\Pi_{t}=\Pi_{H, t} \frac{g\left(S_{t}\right)}{g\left(S_{t-1}\right)}
$$

\footnotetext{
${ }^{11}$ Without loss of generality, we assume that $P_{t}^{*}$ is exogenous and constant $(=1)$ for all $t$.
} 
From (16) and (18), we obtain the real exchange rate $q_{t}$ as the function of $S_{t}$ :

$$
q_{t} \equiv \frac{\mathcal{E}_{t} P_{t}^{*}}{P_{t}}=\frac{S_{t}}{g\left(S_{t}\right)} \equiv q\left(S_{t}\right)
$$

\subsection{Production firms}

Monopolistically competitive firms produce differentiated goods by using capital and labor. Each monopolistic firm $j$ in the home economy produces a differentiated good. The firm's production function is given by

$$
Y_{t}(j)=Z_{t} K_{t}(j)^{\alpha} L_{t}(j)^{1-\alpha}
$$

where $Y_{t}(j), K_{t}(j), L_{t}(j)$, and $Z_{t}$ denote the firm's output level, its capital and labor inputs, and a stochastic productivity shock, respectively.

From the first-order conditions associated with the firm's cost minimization problem, we obtain

$$
(1-\alpha)\left(\frac{R_{t}}{P_{H, t}}\right) K_{t}(j)=\alpha\left(\frac{W_{t}}{P_{H, t}}\right) N_{t}(j)
$$

where $R_{t}$ is the rental rate of capital. The firm's cost minimization implies that the firm's real marginal cost is given by

$$
M C_{t}(j)=M C_{t}=\frac{\left(R_{t} / P_{H, t}\right)^{\alpha}\left(W_{t} / P_{H, t}\right)^{1-\alpha}}{Z_{t} \alpha^{\alpha}(1-\alpha)^{1-\alpha}}
$$


The capital accumulation process in the economy is given as

$$
K_{t+1}=\left[\frac{I_{t}}{K_{t}}-\frac{\phi_{I}}{2}\left(\frac{I_{t}}{K_{t}}-\delta\right)^{2}\right] K_{t}+(1-\delta) K_{t}
$$

where $I_{t}$ is aggregate investment and $\delta$ is the depreciation rate of capital. $\frac{\phi_{I}}{2}\left(\frac{I_{t}}{K_{t}}-\right.$ $\delta)^{2} K_{t}$ denotes the adjustment costs of capital, and $\phi_{I}$ is its parameter value. ${ }^{12} I_{t}$ is composed of domestic and imported goods:

$$
I_{t} \equiv\left[(1-\gamma)^{\frac{1}{\eta}} I_{H, t}^{\frac{\eta-1}{\eta}}+\gamma^{\frac{1}{\eta}} I_{F, t}^{\frac{\eta-1}{\eta}}\right]^{\frac{\eta}{\eta-1}}
$$

where $I_{H, t}$ and $I_{F, t}$ are represented by

$$
I_{H, t} \equiv\left[\int_{0}^{1} I_{H, t}(j)^{\frac{\varepsilon-1}{\varepsilon}} d j\right]^{\frac{\varepsilon}{\varepsilon-1}} ; \quad I_{F, t} \equiv\left[\int_{0}^{1} I_{F, t}(j)^{\frac{\varepsilon-1}{\varepsilon}} d j\right]^{\frac{\varepsilon}{\varepsilon-1}}
$$

From the optimal allocation of expenditure in each goods category, we obtain the following demand functions:

$$
I_{H, t}(j)=\left(\frac{P_{H, t}(j)}{P_{H, t}}\right)^{-\varepsilon} I_{H, t} ; \quad I_{F, t}(j)=\left(\frac{P_{F, t}(j)}{P_{F, t}}\right)^{-\varepsilon} I_{F, t} .
$$

The optimal allocation of expenditures between domestic and imported goods yields

$$
I_{H, t}=(1-\gamma)\left(\frac{P_{H, t}}{P_{t}}\right)^{-\eta} I_{t} ; \quad I_{F, t}=\gamma\left(\frac{P_{F, t}}{P_{t}}\right)^{-\eta} I_{t}
$$

\footnotetext{
${ }^{12}$ The capital (or investment) adjustment cost is widely adopted in dynamic stochastic general equilibrium (DSGE) models, mainly because it generally improves their empirical fit (e.g., Christiano et al. (2005)). Without the adjustment cost, investment would respond to shocks too much compared to empirical evidence. The capital adjustment cost is also important to obtain the price of capital and to generate movements of asset prices. Changes in asset prices provide an amplification mechanism in models with financial frictions (Kiyotaki and Moore (1997); Bernanke et al. (1999)).
} 
From the profit-maximization problem of capital producers, we can obtain the (nominal) price of capital $Q_{t}$ :

$$
Q_{t}=P_{H, t}\left[1-\phi_{I}\left(\frac{I_{t}}{K_{t}}-\delta\right)\right]^{-1}
$$

\subsection{Price setting}

Following Calvo (1983), we assume that in each period, a fraction $1-\zeta$ of monopolistically competitive firms change their prices, whereas a fraction $\zeta$ do not change their prices. This implies that we can express the domestic price index as

$$
P_{H, t} \equiv\left[\zeta P_{H, t-1}^{1-\varepsilon}+(1-\zeta) \bar{P}_{H, t}^{1-\varepsilon}\right]^{\frac{1}{1-\varepsilon}}
$$

where $\bar{P}_{H, t}$ denotes the price reset in period $t$. From (30), we obtain

$$
1=\zeta \Pi_{H, t}^{-1+\varepsilon}+(1-\zeta) \tilde{P}_{H, t}^{1-\varepsilon}
$$

where $\tilde{P}_{H, t} \equiv \frac{\bar{P}_{H, t}}{P_{H, t}}$.

Each firm resets its price to maximize the present discounted value of its profit stream:

$$
\max _{\bar{P}_{H, t}} \sum_{k=0}^{\infty} \zeta^{k} E_{t}\left\{\Lambda_{t, t+k}\left[Y_{t+k \mid t}\left(\bar{P}_{H, t}-M C_{t+k \mid t}^{n}\right)\right]\right\}
$$

subject to

$$
Y_{t+k \mid t}=\left(\frac{\bar{P}_{H, t}}{P_{H, t+k}}\right)^{-\varepsilon} Y_{t+k},
$$

where $Y_{t+k \mid t}$ and $M C_{t+k \mid t}^{n}$ represent the output level and the nominal marginal cost, respectively, in $t+k$ for a firm that last reset its price in period $t . \Lambda_{t, t+k} \equiv$ 
$\beta^{k} \frac{\lambda_{t+k}^{h}}{\lambda_{t}^{h}} \frac{P_{t}}{P_{t+k}}$ is the discount factor. $Y_{t+k}$ is the aggregate output level in period $t+k$. From the first-order condition associated with the above problem, we obtain the optimal price:

$$
\tilde{P}_{H, t}=\frac{\varepsilon}{\varepsilon-1} \frac{\sum_{k=0}^{\infty} \zeta^{k} E_{t}\left\{\Lambda_{t, t+k}\left(\frac{P_{H, t}}{P_{H, t+k}}\right)^{-\varepsilon-1} Y_{t+k} M C_{t+k \mid t}\right\}}{\sum_{k=0}^{\infty} \zeta^{k} E_{t}\left\{\Lambda_{t, t+k}\left(\frac{P_{H, t}}{P_{H, t+k}}\right)^{-\varepsilon} Y_{t+k}\right\}},
$$

which can be rewritten as

$$
\tilde{P}_{H, t}=\frac{\varepsilon}{\varepsilon-1} \frac{X_{t}^{1}}{X_{t}^{2}}
$$

where

$$
X_{t}^{1}=Y_{t} M C_{t}+\zeta E_{t}\left\{\Lambda_{t, t+1} \Pi_{H, t+1}^{\varepsilon+1} X_{t+1}^{1}\right\}
$$

and

$$
X_{t}^{2}=Y_{t}+\zeta E_{t}\left\{\Lambda_{t, t+1} \Pi_{H, t+1}^{\varepsilon} X_{t+1}^{2}\right\}
$$

\subsection{Entrepreneurs}

Entrepreneurs have available net worth $N_{t}$ denominated in domestic currency. To finance the difference between their expenditures on capital goods and their net worth, entrepreneurs borrow from foreign lenders. That is, the entrepreneur finances investment partly with foreign currency denominated debt. The entrepreneur's balance sheet is therefore given by

$$
P_{H, t} N_{t}=Q_{t} K_{t+1}-\mathcal{E}_{t} D_{t}
$$

where $D_{t}$ is the entrepreneur's foreign currency debt position. Note that an unanticipated depreciation reduces net worth in the balance sheet (38), which reflects 
the problem of liability dollarization in emerging market economies.

Following Bernanke et al. (1999), we assume that foreign lenders charge an external finance premium to entrepreneurs owing to asymmetric information. Entrepreneurs choose $D_{t}$ and $K_{t+1}$ so that the expected return on capital $\left(R^{K}\right)$ equals the cost of foreign borrowing:

$$
R_{t+1}^{K}=\left(1+\tau_{e, t}\right)\left(1+i_{t}^{*}\right)\left(\frac{\mathcal{E}_{t+1}}{\mathcal{E}_{t}}\right) F_{t}
$$

where $F_{t}$ is the external finance premium and $\tau_{e, t}$ is a tax on the entrepreneur's foreign borrowing. Following Céspedes et al. (2004), we assume that the external finance premium is an increasing function of the value of capital relative to net worth:

$$
F_{t}=\Psi\left(\frac{Q_{t} K_{t+1}}{P_{H, t} N_{t}}\right), \quad \Psi(1)=1, \quad \Psi^{\prime}(.)>1,
$$

where the functional form for $\Psi$ is given by $\Psi(g)=g^{\mu}(\mu>0) .{ }^{13}$

At the beginning of each period, entrepreneurs collect returns from capital and repay their foreign debt. Following Céspedes et al. (2004) and Elekdağ and Tchakarov (2007), we assume that entrepreneurs consume a fraction $1-\omega$ of the remainder on imports. The evolution of net worth is thus given as

$$
P_{H, t} N_{t}=\omega\left[R_{t}^{K} Q_{t-1} K_{t}-\left(1+\tau_{e, t-1}\right)\left(1+i_{t-1}^{*}\right) F_{t-1} \mathcal{E}_{t} D_{t-1}+T_{e, t}\right],
$$

\footnotetext{
${ }^{13}$ Bernanke et al. (1999) show that given the assumptions related to the agency problem including the characteristics of the distribution of an idiosyncratic return shock, parameter values associated with monitoring costs, and constant returns to scale in production and monitoring costs, the agency problem implies that the external finance premium is an increasing function of the ratio of capital to net worth as in Eq.(40). Especially, the assumption of constant returns to scale in production and monitoring costs is important for the aggregation so that the value of capital relative to net worth and the external premium become equal across all entrepreneurs.
} 
where $T_{e, t}$ denotes a lump-sum transfer from the government.

Finally, the return on capital for entrepreneurs $R_{t+1}^{K}$ is expressed by the sum of the rental rate of capital $R_{t+1}$ and the return from capital investment, divided by the original price of capital $Q_{t}$ :

$$
R_{t+1}^{K}=\frac{R_{t+1}}{Q_{t}}+\frac{Q_{t+1}}{Q_{t}}\left[(1-\delta)+\phi_{I}\left(\frac{I_{t+1}}{K_{t+1}}-\delta\right) \frac{I_{t+1}}{K_{t+1}}-\frac{\phi_{I}}{2}\left(\frac{I_{t+1}}{K_{t+1}}-\delta\right)^{2}\right]
$$

\subsection{Government}

We assume that the government transfers the collected tax on foreign debt to households and entrepreneurs in a lump-sum manner. The government's budget constraints are thus given by

$$
\tau_{h, t-1}\left(1+i_{t-1}^{*}\right) \mathcal{E}_{t} B_{t-1}=T_{h, t}
$$

and

$$
\tau_{e, t-1}\left(1+i_{t-1}^{*}\right) F_{t-1} \mathcal{E}_{t} D_{t-1}=T_{e, t} .
$$

\subsection{Equilibrium and exogenous shocks}

The market clearing for domestic goods requires

$$
P_{H, t} Y_{t}=P_{H, t} C_{H, t}+P_{H, t} I_{H, t}+\mathcal{E}_{t} E X_{t},
$$


where $E X_{t}$ denotes demand for exports, which is assumed to be an exogenous stochastic process. Dividing both sides of (45) by $P_{H, t}$ we obtain

$$
\begin{aligned}
Y_{t} & =C_{H, t}+I_{H, t}+S_{t} E X_{t} \\
& =(1-\gamma) g\left(S_{t}\right)^{\eta}\left(C_{t}+I_{t}\right)+S_{t} E X_{t},
\end{aligned}
$$

where we derive the second equality by considering the demand functions (7), (18), and (28).

From Eq.(21) and the fact that the production function is homogeneous with degree 1 , we obtain

$$
\int_{0}^{1} Y_{t}(j) d j=Z_{t} K_{t}^{\alpha} L_{t}^{1-\alpha}
$$

where $K_{t}=\int_{0}^{1} K_{t}(j) d j$ and $L_{t}=\int_{0}^{1} L_{t}(j) d j$. From the demand function for differentiated goods, we obtain

$$
\int_{0}^{1}\left(\frac{P_{H, t}(j)}{P_{H, t}}\right)^{-\varepsilon} Y_{t} d j=Z_{t} K_{t}^{\alpha} L_{t}^{1-\alpha}
$$

We define $\theta_{t} \equiv \int_{0}^{1}\left(\frac{P_{H, t}(j)}{P_{H, t}}\right)^{-\varepsilon} d j$, which can be expressed as ${ }^{14}$

$$
\theta_{t}=(1-\zeta) \tilde{P}_{H, t}^{-\varepsilon}+\zeta \Pi_{H, t}^{\varepsilon} \theta_{t-1}
$$

Then, we can rewrite (49) as

$$
Y_{t}=\theta_{t}^{-1} Z_{t} K_{t}^{\alpha} L_{t}^{1-\alpha}
$$

\footnotetext{
${ }^{14}$ For the derivation of (50), see Schmitt-Grohé and Uribe (2006).
} 
where $\theta_{t}$ measures the resource costs induced by price dispersion in the Calvo model.

The productivity shock $Z_{t}$, export shock $E X_{t}$, and foreign (nominal) interestrate shock $i_{t}^{*}$ are exogenously evolving according to the following processes:

$$
\begin{gathered}
\log Z_{t}=\left(1-\rho_{z}\right) \log Z+\rho_{z} \log Z_{t-1}+\varepsilon_{z, t}, \quad \varepsilon_{z, t} \sim i . i . d . \quad N\left(0, \sigma_{z}^{2}\right), \\
\log E X_{t}=\left(1-\rho_{e x}\right) \log E X+\rho_{e x} \log E X_{t-1}+\varepsilon_{e x, t}, \quad \varepsilon_{e x, t} \sim \text { i.i.d. } N\left(0, \sigma_{e x}^{2}\right),
\end{gathered}
$$

and

$$
i_{t}^{*}=\left(1-\rho_{i}\right) i^{*}+\rho_{i} i_{t-1}^{*}+\varepsilon_{i, t}, \quad \varepsilon_{i, t} \sim \text { i.i.d. } N\left(0, \sigma_{i}^{2}\right) .
$$

The equilibrium of this economy is a set of stationary stochastic processes $\left\{C_{t}\right.$, $L_{t}, B_{t}, \Pi_{t}, S_{t}, \frac{P_{t}}{P_{H, t}}, \Pi_{H, t}, q_{t}, Y_{t}, M C_{t}, K_{t}, I_{t}, \frac{Q_{t}}{P_{H, t}}, \tilde{P}_{H, t}, N_{t}, R_{t}^{K}, F_{t}, D_{t}, \frac{R_{t}}{P_{t}}, \frac{W_{t}}{P_{t}}, X_{t}^{1}$, $\left.X_{t}^{2}, \theta_{t}, i_{t}, \mathcal{E}_{t}\right\}_{t=0}^{\infty}$ satisfying Eqs. (10)-(14), (17)-(20), (22)-(24), (29), (35)-(37), (38)-(42), (47), (50), and (51) (combined with the equations for other variables), given initial values for $B_{-1}, K_{0}, N_{-1}$, and $D_{-1}$, and exogenous stochastic processes $Z_{t}, E X_{t}$, and $i_{t}^{*}$.

\subsection{Optimal Ramsey policies}

We consider optimal Ramsey monetary and capital control policies. We obtain the Ramsey optimal policies by setting up a Lagrangian problem in which the social planner maximizes the conditional lifetime utility of the representative household subject to the first-order conditions of the private agents and the market-clearing conditions of the economy. We compute this numerically using the Matlab proce- 
dures developed by Levin et al. (2006). ${ }^{15}$

We let $x_{t}$ denote the $N \times 1$ vector of endogenous variables. Except for the policy instrument, the remaining $N-1$ endogenous variables in $x_{t}$ satisfy the $N-1$ structural conditions, which is expressed with

$$
E_{t} f\left(x_{t}, x_{t+1}, \zeta_{t}\right)=0
$$

where the vector $\zeta_{t}$ denotes the exogenous variables. We derive the optimal Ramsey policy from the maximization problem:

$$
\begin{aligned}
& \max _{\left\{x_{t}\right\}_{t=0}^{\infty}} E_{0} \sum_{t=0}^{\infty} \beta^{t} U\left(x_{t}, \zeta_{t}\right) \\
& \text { s.t. } \quad E_{t} f\left(x_{t}, x_{t+1}, \zeta_{t}\right)=0 .
\end{aligned}
$$

We set up a Lagrangian problem:

$$
\mathcal{L}_{0}=E_{0} \sum_{t=0}^{\infty} \beta^{t}\left\{U\left(x_{t}, \zeta_{t}\right)+\lambda_{t}^{\prime} f\left(x_{t}, x_{t+1}, \zeta_{t}\right)\right\},
$$

where $\lambda_{t}$ denotes the Lagrange multipliers associated with the first-order conditions of the private agents and the market-clearing conditions of the economy in (55). Taking derivatives of $\mathcal{L}_{0}$ with respect to the $N$ endogenous variables, we obtain the $N$ first order conditions which are characterized by the following equation: ${ }^{16}$

$$
U_{1}\left(x_{t}, \zeta_{t}\right)+E_{t} \lambda_{t}^{\prime} f_{1}\left(x_{t}, x_{t+1}, \zeta_{t}\right)+\beta^{-1} \lambda_{t-1}^{\prime} f_{2}\left(x_{t-1}, x_{t}, \zeta_{t-1}\right)=0
$$

\footnotetext{
${ }^{15}$ Levin et al. (2006)'s program reads a Dynare model file and generates the first-order conditions of a Ramsey policymaker. See Adjemian et al. (2011) for details on Dynare.

${ }^{16}$ The first order necessary condition for optimality at $t=0$ is (58) with $\lambda_{-1}=0$.
} 
Taking derivatives of $\mathcal{L}_{0}$ with respect to $\lambda_{t}$, we obtain the $N-1$ equilibrium conditions in the private sector in (55). The Ramsey equilibrium process is therefore characterized by the $N-1$ equations, (55), and the $N$ equations (58). We have the $N$ elements of $x$ and the $N-1$ multipliers, $\lambda$. In total, there are $2 N-1$ variables and $2 N-1$ equations.

In Section 3, we will examine the optimal Ramsey monetary and capital control policies. In the peg case without capital controls (i.e, $\mathcal{E}_{t}=\overline{\mathcal{E}}$, and $\tau_{h, t}=\tau_{e, t}=0$ for all $t$ ), we have $N$ endogenous variables and $N$ equilibrium conditions. In the peg case with the optimal capital control policies, we include $\tau_{h, t}$ and/or $\tau_{e, t}$ in the endogenous variables and obtain the Ramsey capital control policies by letting $\tau_{h, t}$ and/or $\tau_{e, t}$ be policy instruments. In this case, we have $N-1$ (or $N-2$ ) equilibrium conditions for $N$ endogenous variables. Including the $N-1$ (or $N-2$ ) multipliers, in total, we have $2 N-1$ (or $2 N-2$ ) variables and $2 N-1$ (or $2 N-2$ ) equations. In the flexible exchange rate case in which $\mathcal{E}_{t}$ is included in the endogenous variables, we let $i_{t}$ be a policy instrument and obtain the Ramsey monetary policy. In this case, we have $N-1$ equilibrium conditions for $N$ endogenous variables. Including the $N-1$ multipliers, in total, we have $2 N-1$ variables and $2 N-1$ equations.

\subsection{Parameterization}

We choose standard parameter values given in the relevant literature, which are summarized in Table 1. Following many previous studies, we set the quarterly discount factor $\beta$ to 0.99. Following Elekdağ and Tchakarov (2007) and Devereux et al. (2006), we set the inverse of intertemporal elasticity of substitution $\sigma$, elasticity of labor supply $\phi$, and capital adjustment cost parameter $\psi^{K}$ to 2 , 1 , and 
12, respectively. We set capital share in production $\alpha$ to 0.32 as in Schmitt-Grohé and Uribe (2003). Following Kollmann (2002) and Devereux et al. (2006), we set the quarterly depreciation rate $\delta$ to 0.025. Following Galí and Monacelli (2005), we set the elasticity of substitution among differentiated goods $\epsilon$ and fraction of firms that do not reset their prices $\zeta$ to 6 and 0.75 , respectively. As in Ravenna and Natalucci (2008), we set the elasticity of substitution between domestic and foreign goods $\eta$ to 1.5. With respect to the degree of openness $\gamma$, we follow Cook (2004) and set it to 0.28. The parameter for bond adjustment cost $\psi^{B}$ and steady state debt ratio to GDP $\frac{B}{Y}$ are set to 0.0007 and 0.4 , respectively, as in Devereux et al. (2006). We set the steady state level of leverage ratio $\frac{Q K}{P_{H} N}$ at 2.2 , which is higher than in Bernanke et al. (1999) who use 2, but not as high as in Devereux et al. (2006) who use 3. Following Cespedes et al. (2000) and Merola (2010), we set the elasticity of external finance premium to leverage ratio $\mu$ to $0.02 .{ }^{17}$ We use the same values as in Elekdağ and Tchakarov (2007) for the exogenous shocks. The persistence and the standard deviation of the productivity shock $\left(\rho_{z}\right.$ and $\left.\sigma_{z}\right)$ are set to 0.8 and 0.02 , respectively. The persistence and the standard deviation of the export shock $\left(\rho_{e x}\right.$ and $\sigma_{e x}$ ) are set to 0.5 and 0.06 , respectively. The persistence and the standard deviation of the foreign interest shock $\left(\rho_{i}\right.$ and $\left.\sigma_{i}\right)$ are set to 0.8 and 0.003 , respectively.

\subsection{Welfare evaluation}

We calculate and compare welfare levels under alternative policy regimes. Since there exist households and entrepreneurs in our model, the overall welfare mea-

\footnotetext{
${ }^{17}$ Using a maximum-likelihood procedure and post-1979 US data, Christensen and Dib (2008) report a higher estimated value of 0.042 for this parameter.
} 
Table 1: Parameterization.

\begin{tabular}{lll}
\hline Parameters & Value & \\
\hline$\beta$ & 0.99 & Discount factor \\
$\sigma$ & 2 & Inverse of intertemporal elasticity of substitution \\
$\phi$ & 1 & Elasticity of labor supply \\
$\psi^{K}$ & 12 & Capital adjustment cost parameter \\
$\alpha$ & 0.32 & Share of capital in output \\
$\delta$ & 0.025 & Depreciation rate of capital \\
$\epsilon$ & 6 & Elasticity of substitution among differentiated goods \\
$\zeta$ & 0.75 & Fraction of firms that do not reset their prices \\
$\eta$ & 1.5 & Elasticity of substitution between domestic and foreign goods \\
$\gamma$ & 0.28 & Degree of openness \\
$\psi^{B}$ & 0.0007 & Parameter for bond adjustment cost \\
$\frac{B}{Y}$ & 0.4 & Steady-state ratio of debt to GDP \\
$\frac{Q K}{P_{H} N}$ & 2.2 & Steady-state ratio of capital to net worth \\
$\mu$ & 0.02 & Elasticity of external finance premium \\
$\rho_{Z}$ & 0.8 & Persistence: productivity shock \\
$\sigma_{Z}$ & 0.02 & Standard deviation: productivity shock \\
$\rho_{e x}$ & 0.5 & Persistence: export shock \\
$\sigma_{e x}$ & 0.06 & Standard deviation: export shock \\
$\rho_{i}$ & 0.8 & Persistence: foreign interest rate shock \\
$\sigma_{i}$ & 0.003 & Standard deviation: foreign interest rate shock \\
\hline
\end{tabular}


sure of the eocnomy is the weighted sum of households' and entrepreneurs' welfare. However, as argued by Bernanke et al. (1999), we can reasonably assume that the fraction of entepreneurs' consumption is negligible. Following Faia and Monacelli (2005) and Elekdağ and Tchakarov (2007), we therefore assume that the entepreneurs' share of consumption is negligible and the overall welfare measure of the eocnomy corresponds to the households' welfare level. We let $V_{0}^{a}$ denote the conditional welfare level associated with case $(a)(a=\mathrm{i}$, ii, iii...):

$$
\begin{aligned}
V_{0}^{a} & \equiv E_{0} \sum_{t=0}^{\infty} \beta^{t} U\left(C_{t}^{a}, L_{t}^{a}\right), \\
& =E_{0} \sum_{t=0}^{\infty} \beta^{t} U\left(\left(1-\lambda^{a}\right) C, L\right) .
\end{aligned}
$$

Here, $\lambda^{a}$ is the welfare cost of adopting policy $(a)$ on the condition of the calibrated steady state. The conditional welfare measure is obtained using the secondorder perturbation methods as described in Schmitt-Grohé and Uribe (2004) and Schmitt-Grohé and Uribe (2007). ${ }^{18}$ We let the most welfare-maximizing case be the reference case $(r e f)$. Therefore, $\lambda^{a}-\lambda^{r e f}$ is the welfare loss in each case, which is the fraction of consumption that compensates a household to a level that is considered as well off under policy $(a)$ as in the reference case $(r e f)$.

\section{Results}

In this section, we present the main results of our analysis. We evaluate the welfare implications of alternative policy and exchange rate regimes with and without the financial accelerator. In Section 3.1, we consider an economy without the financial

\footnotetext{
${ }^{18} \mathrm{Kim}$ and Kim (2003) reveal that second-order solutions are necessary because conventional linearization may generate spurious welfare reversals.
} 
accelerator and compare the welfare consequences of an optimal monetary policy under flexible exchange rates (policy instrument $i_{t}$ ), an optimal capital control policy on households under fixed exchange rates (policy instrument $\tau_{h}, \mathcal{E}_{t}=\overline{\mathcal{E}}$ for all $t$ ), and a peg regime without an optimal capital control policy $\left(\mathcal{E}_{t}=\overline{\mathcal{E}}\right.$ for all $\left.t\right)$. In Section 3.2, we analyze an economy with the financial accelerator and compare the welfare consequences of an optimal monetary policy under flexible exchange rates (policy instrument $i_{t}$ ), an optimal capital control policy on households under fixed exchange rates (policy instrument $\tau_{h}, \mathcal{E}_{t}=\overline{\mathcal{E}}$ for all $t$ ), an optimal capital control policy on entrepreneurs (policy instrument $\tau_{e}, \mathcal{E}_{t}=\overline{\mathcal{E}}$ for all $t$ ), optimal capital control policies on households and entrepreneurs (policy instruments $\tau_{h}$ and $\tau_{e}, \mathcal{E}_{t}=\overline{\mathcal{E}}$ for all $t$ ), and a peg regime without optimal capital control policy $\left(\mathcal{E}_{t}=\overline{\mathcal{E}}\right.$ for all $\left.t\right)$.

\subsection{No financial accelerator}

Following Devereux et al. (2006), we also examine the model without entrepreneurs in order to explore the importance of the balance sheet effect. In this case, households accumulate capital without the external finance premium. The Appendix explains the model without entrepreneurs in detail.

We compare welfare levels in an economy without the financial accelerator in the following cases: (i) an optimal monetary policy under flexible exchange rates (policy instrument $i_{t}$ ), (ii) an optimal capital control policy under fixed exchange rates (policy instrument $\tau_{h}, \mathcal{E}_{t}=\overline{\mathcal{E}}$ for all $t$ ), and (iii) a fixed exchange rate regime (without capital controls, $\mathcal{E}_{t}=\overline{\mathcal{E}}$ for all $t$ ). Since the optimal monetary policy case under flexible exchange rates (i) turns out to be the most welfare-maximizing, we 
Table 2: Conditional welfare costs: No financial accelerator

$$
\text { (i) Mon. (ii) Cap. Con. (iii) Fixed ER }
$$

\begin{tabular}{llll}
\hline Welfare Cost: & & \\
$\left(\lambda^{a}-\lambda^{\text {ref }}\right) \times 100$ & 0 & 0.106 & 0.306 \\
\hline
\end{tabular}

Note) The conditional welfare costs in (ii) and (iii) are measured with the most welfaremaximizing case (i) being the reference case.

let (i) to be the reference case $(r e f)$.

The conditional welfare costs in each case (i, ii, and iii) compared with the reference case $(r e f)$ are shown in Table 2. The welfare cost in the case of an optimal capital control policy under fixed exchange rates (ii) is $0.106 \%$, whereas the welfare cost in the fixed exchange rate regime (iii) is $0.306 \%$. Hence, we can say that the optimal capital control policy more than halves the welfare gap between the flexible exchange rate case (i) and the fixed exchange rate case (iii). However, it is obvious that the optimal monetary policy under flexible exchange rates (i) outperforms the optimal capital control policy under fixed exchange rates (ii) in an economy without the financial accelerator.

Tables 3 and 4 show the means and standard deviations of the main variables in the case without the financial accelerator. Since the capital control policy is adopted only in case (ii), by definition, the means and standard deviations of $\tau_{h}$ in cases (i) and (iii) are zero in Tables 3 and 4 . Since the fixed exchange rate eliminates the volatility of the nominal exchange rate, by definition, the standard deviation of $\Delta \mathcal{E}$ in cases (ii) and (iii) is zero in Table 4 . Further, note that since the optimal monetary policy under flexible exchange rates (i) is an "inward looking" policy, it has the lowest domestic price inflation $\left(\Pi_{H}\right)$ volatility among the three regimes in Table 4. In contrast, since the optimal capital control policy under 
Table 3: Means: No financial accelerator

\begin{tabular}{lccc}
\hline & (i) Mon. & (ii) Cap. Con. & (iii) Fixed ER \\
\hline$Y$ & 1.8042 & 1.8042 & 1.7987 \\
$C$ & 1.4571 & 1.4565 & 1.4535 \\
$I$ & 0.3426 & 0.3422 & 0.3420 \\
$L$ & 0.6943 & 0.6944 & 0.6944 \\
$\Delta \mathcal{E}$ & 1.0000 & 1.0000 & 1.0000 \\
$S$ & 0.9968 & 0.9967 & 0.9945 \\
$\Pi$ & 1.0000 & 1.0000 & 1.0000 \\
$\Pi_{H}$ & 1.0000 & 1.0000 & 1.0000 \\
$i_{d}$ & 0.0099 & 0.0099 & 0.0100 \\
$\tau_{h}$ & 0.0000 & -0.0001 & 0.0000 \\
\hline
\end{tabular}

fixed exchange rates (ii) and the fixed exchange rate regime (iii) are "outward looking" policies, the terms of trade $(S)$ in (ii) and (iii) are more stabilized (i.e., the standard deviations of $S$ in (ii) and (iii) are smaller) compared to that in case (i) in Table 4.

\subsection{With financial accelerator}

We next consider alternative policies in an economy with the financial accelerator. We compare the welfare levels in the following cases: (i) optimal capital controls on both households and entrepreneurs under fixed exchange rates (policy instruments $\tau_{h}$ and $\tau_{e}, \mathcal{E}_{t}=\overline{\mathcal{E}}$ for all $t$ ), (ii) optimal capital controls on entrepreneurs under fixed exchange rates (policy instrument $\tau_{e}, \mathcal{E}_{t}=\overline{\mathcal{E}}$ for all $t$ ), (iii) an optimal monetary policy under flexible exchange rates (policy instrument $i_{t}$ ), (iv) optimal capital controls on households under fixed exchange rates (policy instrument $\tau_{h}, \mathcal{E}_{t}=\overline{\mathcal{E}}$ for all $t$ ), and (v) a fixed exchange rate regime (without capital controls, $\mathcal{E}_{t}=\overline{\mathcal{E}}$ for all $t$ ). Since optimal capital controls on both households and entrepreneurs under 
Table 4: Standard Deviations (\%): No financial accelerator

\begin{tabular}{lccc}
\hline & (i) Mon. & (ii) Cap. Con. & (iii) Peg \\
\hline$Y$ & 3.55 & 3.21 & 2.97 \\
$C$ & 1.67 & 2.06 & 1.40 \\
$I$ & 7.60 & 10.13 & 6.17 \\
$L$ & 0.86 & 1.93 & 3.62 \\
$\Delta \mathcal{E}$ & 2.75 & 0.00 & 0.00 \\
$S$ & 4.06 & 2.14 & 2.63 \\
$\Pi$ & 0.79 & 0.19 & 0.59 \\
$\Pi_{H}$ & 0.05 & 0.27 & 0.81 \\
$i_{d}$ & 1.00 & 0.96 & 0.50 \\
$\tau_{h}$ & 0.00 & 1.05 & 0.00 \\
\hline
\end{tabular}

fixed exchange rates (i) is the most welfare-maximizing, we let (i) be the reference case $(r e f)$.

We show the welfare ranking for the alternative regimes in Table 5. It should be noted that the optimal monetary policy under flexible exchange rates (iii), which was the most welfare-maximizing in the previous subsection 3.1 for the economy without the financial accelerator, is now ranked third. As argued above, the most welfare-maximizing is optimal capital controls on both households and entrepreneurs under fixed exchange rates (i). Optimal capital controls on households (iv) improves the welfare level of the economy under fixed exchange rates (v). However, the welfare-improving effect of optimal capital controls on households (iv) is limited. Optimal capital controls on households (iv) is inferior to the optimal monetary policy under flexible exchange rates (iii). In contrast, optimal capital controls on entrepreneurs (ii) outperforms the optimal monetary policy (iii). Further, optimal capital controls on entrepreneurs (ii) is second only to the most welfare-maximizing case (i). 
Table 5: Conditional welfare costs: With financial accelerator

\begin{tabular}{lccccc}
\hline & $\begin{array}{c}\text { (i) Cap. Con. } \\
\text { ent. \& hous. }\end{array}$ & $\begin{array}{c}\text { (ii) Cap. Con. } \\
\text { ent. }\end{array}$ & (iii) Mon. & $\begin{array}{c}\text { (iv) Cap. Con. } \\
\text { hous. }\end{array}$ & (v) Peg \\
\hline $\begin{array}{l}\text { Welfare Cost: } \\
\left(\lambda^{a}-\lambda^{\text {ref }}\right) \times 100\end{array}$ & 0 & 0.215 & 1.624 & 1.900 & 2.385 \\
\hline
\end{tabular}

Note) The conditional welfare costs in (ii) to (v) are measured with the most welfare-maximizing case (i) being the reference case.

Tables 6 and 7 show the means and standard deviations of the main variables in the case with the financial accelerator. Comparing column (v) in Table 7 to column (iii) in Table 4, we can see that the standard deviations of $Y, C, I, L$, $S, \Pi$, and $\Pi_{H}$ in column (v) are larger, which implies that the introduction of a financial accelerator mechanism into an economy increases the volatilities of the economy to the same shocks. Figure 1 represents the impulse responses of $Y$, $C, I, L, S, \Pi$, and $\Pi_{H}$ to a foreign interest rate shock in the peg case with and without the financial accelerator. From Figure 1, we can also confirm that the financial accelerator makes the economy more volatile. It should be noted that in Table 6, the mean of the external finance premium $F$ is the lowest in case (ii) and second-lowest in case (i). We can say that capital controls on entrepreneurs curtail the external finance premium level more significantly than a monetary policy or capital controls on households.

The intuition underlying our analysis results is as follows. Entrepreneurs finance investment partly with foreign borrowing, which is subject to financial frictions. Entrepreneurs borrow abroad at an interest rate, which is equal to the foreign interest rate, adjusted for expected exchange rate fluctuations, and aug- 
Table 6: Means: With financial accelerator

\begin{tabular}{lccccc}
\hline & $\begin{array}{c}\text { (i) Cap. Con. } \\
\text { ent. \& hous. }\end{array}$ & $\begin{array}{c}\text { (ii) Cap. Con. } \\
\text { ent. }\end{array}$ & (iii) Mon. & (iv) Cap. Con. & (v) Peg \\
hous. & \\
\hline$Y$ & 1.7327 & 1.7295 & 1.7136 & 1.7065 & 1.6948 \\
$C$ & 1.2672 & 1.2647 & 1.2533 & 1.2495 & 1.2409 \\
$I$ & 0.2348 & 0.2341 & 0.2238 & 0.2204 & 0.2163 \\
$L$ & 0.7819 & 0.7825 & 0.7865 & 0.7874 & 0.7894 \\
$\Delta \mathcal{E}$ & 1.0000 & 1.0000 & 1.0001 & 1.0000 & 1.0000 \\
$S$ & 0.9966 & 0.9957 & 0.9958 & 0.9935 & 0.9915 \\
$\Pi$ & 1.0000 & 1.0000 & 1.0001 & 1.0000 & 1.0000 \\
$\Pi_{H}$ & 1.0000 & 1.0000 & 1.0001 & 1.0000 & 1.0000 \\
$i_{d}$ & 0.0098 & 0.0100 & 0.0099 & 0.0096 & 0.0100 \\
$F$ & 1.0109 & 1.0107 & 1.0153 & 1.0164 & 1.0173 \\
$\tau_{h}$ & -0.0002 & 0.0000 & 0.0000 & -0.0002 & 0.0000 \\
$\tau_{e}$ & 0.0031 & 0.0034 & 0.0000 & 0.0000 & 0.0000 \\
\hline
\end{tabular}

Table 7: Standard Deviations (\%): With financial accelerator

\begin{tabular}{lccccc}
\hline & $\begin{array}{c}\text { (i) Cap. Con. } \\
\text { ent. \& hous. }\end{array}$ & $\begin{array}{c}\text { (ii) Cap. Con. } \\
\text { ent. }\end{array}$ & (iii) Mon. & $\begin{array}{c}\text { (iv) Cap. Con. } \\
\text { hous. }\end{array}$ & (v) Peg \\
\hline$Y$ & 2.83 & 3.13 & 3.77 & 2.88 & 3.52 \\
$C$ & 2.69 & 1.69 & 2.04 & 3.17 & 2.04 \\
$I$ & 7.12 & 10.23 & 9.17 & 8.73 & 11.02 \\
$L$ & 3.35 & 3.48 & 2.43 & 3.90 & 4.50 \\
$\Delta \mathcal{E}$ & 0.00 & 0.00 & 4.61 & 0.00 & 0.00 \\
$S$ & 1.75 & 2.81 & 5.13 & 1.91 & 2.85 \\
$\Pi$ & 0.21 & 0.57 & 1.46 & 0.19 & 0.65 \\
$\Pi_{H}$ & 0.30 & 0.79 & 0.29 & 0.26 & 0.91 \\
$i_{d}$ & 1.31 & 0.50 & 2.05 & 1.68 & 0.50 \\
$F$ & 0.10 & 0.17 & 0.20 & 0.15 & 0.34 \\
$\tau_{h}$ & 1.40 & 0.00 & 0.00 & 1.85 & 0.00 \\
$\tau_{e}$ & 0.83 & 1.31 & 0.00 & 0.00 & 0.00 \\
\hline
\end{tabular}



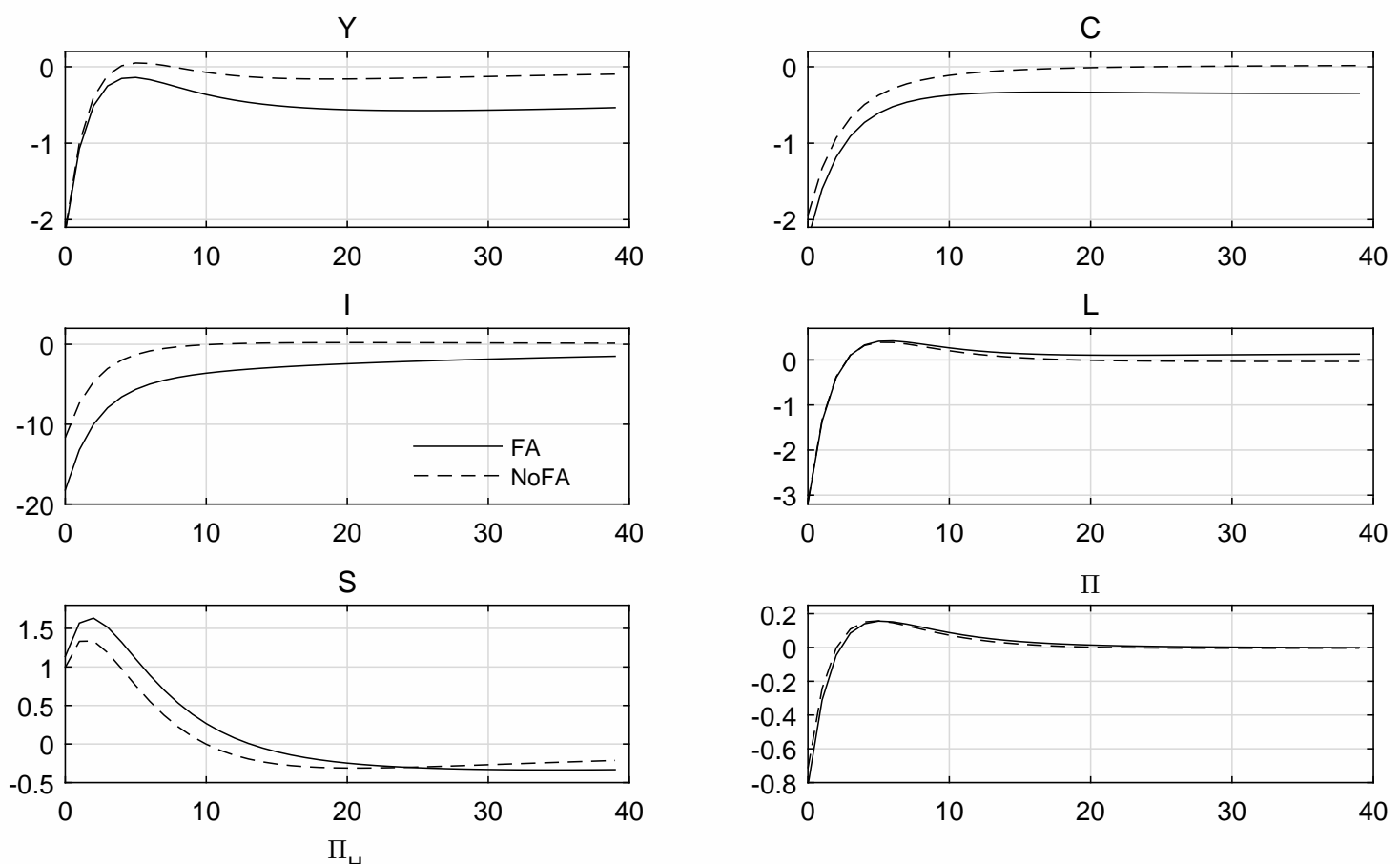

Figure 1: Model with $(-)$ and without $(--)$ the financial accelerator; Peg case: Impulse responses to a foreign interest rate shock 
mented by an external finance premium. Although it affects the economy through domestic interest rates, a monetary policy does not directly affect the interest rate at which entrepreneurs borrow from abroad. In contrast, capital controls on entrepreneurs have a direct control on the interest rate at which entrepreneurs borrow from foreign lenders, and may yield higher welfare in an economy with the financial accelerator.

\section{Sensitivity analysis}

In this section, we examine the robustness of our analysis results in the previous section. In the previous section, we showed the welfare rankings in the case in which all the shocks are included. In this section, we will show that our results are robust even when we consider these shocks individually.

First, we considered the welfare rankings in an economy without the financial accelerator. Table 2 shows the welfare ranking in the case in which all the three shocks are included. The welfare rankings for the individual shocks, which are productivity shock, export shock, and foreign interest shock, are shown in Tables 8, 9, and 10, respectively. In Tables 8, 9, and 10, we can see that the optimal monetary policy under flexible exchange rates (i) outperforms the optimal capital control policy under fixed exchange rates (ii). The welfare rankings for individual shocks in Tables 8, 9, and 10 are then identical to that for all the shocks in Table 2. Therefore, we confirm that our results are robust even when we consider the individual shocks in an economy without the financial accelerator.

However, there are some notable differences among the three cases. Comparing Tables 8,9 , and 10, we can see that the welfare benefit of monetary policy (i.e., the 
difference between (i) and (iii)) is the largest for the productivity shock but the smallest for the foreign interest shock. Another notable difference is that although the capital control policy is not as good as the monetary policy in any case, the capital control policy is the closest to the monetary policy for the foreign interest shock (i.e., (ii) in Table 10 is smaller than that in Tables 8 and 9).

Table 8: Conditional welfare costs: No financial accelerator - Productivity shock

\begin{tabular}{lccc}
\hline & (i) Mon. & (ii) Cap. Con. & (iii) Fixed ER \\
\hline $\begin{array}{l}\text { Welfare Cost: } \\
\left(\lambda^{a}-\lambda^{\text {ref }}\right) \times 100\end{array}$ & 0 & 0.056 & 0.182 \\
\hline
\end{tabular}

Table 9: Conditional welfare costs: No financial accelerator - Export shock

\begin{tabular}{lccc}
\hline & (i) Mon. & (ii) Cap. Con. & (iii) Fixed ER \\
\hline $\begin{array}{l}\text { Welfare Cost: } \\
\left(\lambda^{a}-\lambda^{r e f}\right) \times 100\end{array}$ & 0 & 0.044 & 0.075 \\
\hline
\end{tabular}

Table 10: Conditional welfare costs: No financial accelerator - Foreign interest shock
(i) Mon.
(ii) Cap. Con.
(iii) Fixed ER

\begin{tabular}{llll}
\hline Welfare Cost: & & \\
$\left(\lambda^{a}-\lambda^{r e f}\right) \times 100$ & 0 & 0.007 & 0.049 \\
\hline
\end{tabular}

Next, we consider the welfare rankings in an economy with the financial accelerator. Table 5 shows the welfare ranking in the case in which all the three shocks are included. The welfare rankings for the individual shocks, which are productivity shock, export shock, and foreign interest shock, are shown in Tables 11, 12, and 
13, respectively. In Tables 11, 12, and 13, we can see that the welfare rankings for individual shocks are identical to that for all the shocks in Table 5. Therefore, we confirm that our results are robust even when we consider the individual shocks in an economy with the financial accelerator.

However, there are some notable differences among the three cases. Comparing Tables 11, 12, and 13, we can see that the welfare benefit of capital controls (i.e., the difference between $(\mathrm{i})$ and $(\mathrm{v})$ ) is the largest for the foreign interest shock. Another notable difference is that the monetary policy is furthest behind capital controls for the foreign interest shock (i.e., the difference between (i) and (iii) in Table 13 is larger than that in Tables 11 and 12).

Table 11: Conditional welfare costs: With financial accelerator - Productivity shock
(i) Cap. Con. ent. \& hous.
(ii) Cap. Con. ent.
(iii) Mon. (iv) Cap. Con. hous.

\section{Welfare Cost:}

$\left(\lambda^{a}-\lambda^{r e f}\right) \times 100$

0

0.123

1.663

1.741

1.922

Table 12: Conditional welfare costs: With financial accelerator - Export shock

\begin{tabular}{lccccc}
\hline & $\begin{array}{c}\text { (i) Cap. Con. } \\
\text { ent. \& hous. }\end{array}$ & $\begin{array}{c}\text { (ii) Cap. Con. } \\
\text { ent. }\end{array}$ & (iii) Mon. & $\begin{array}{c}\text { (iv) Cap. Con. (v) Peg } \\
\text { hous. }\end{array}$ & \\
\hline $\begin{array}{l}\text { Welfare Cost: } \\
\left(\lambda^{a}-\lambda^{\text {ref }}\right) \times 100\end{array}$ & 0 & 0.049 & 1.630 & 1.757 & 1.871 \\
\hline
\end{tabular}


Table 13: Conditional welfare costs: With financial accelerator - Foreign interest shock

\begin{tabular}{lccccc}
\hline & $\begin{array}{c}\text { (i) Cap. Con. } \\
\text { ent. \& hous. }\end{array}$ & $\begin{array}{c}\text { (ii) Cap. Con. } \\
\text { ent. }\end{array}$ & (iii) Mon. & $\begin{array}{c}\text { (iv) Cap. Con. } \\
\text { hous. }\end{array}$ & (v) Peg \\
\hline $\begin{array}{l}\text { Welfare Cost: } \\
\left(\lambda^{a}-\lambda^{\text {ref }}\right) \times 100\end{array}$ & 0 & 0.043 & 1.800 & 1.870 & 2.064 \\
\hline
\end{tabular}

\section{Conclusion}

We have developed a small open economy, New Keynesian model that highlights the vulnerability of balance sheets to exchange rate fluctuations. We then apply a Ramsey-type analysis and examine the welfare implications of optimal monetary and capital control policies. To our knowledge, our paper is the first that examines the welfare implications of optimal capital control policies in a small open economy, New Keynesian model that incorporates a financial accelerator coupled with liability dollarization.

In the case without the financial accelerator, we have compared three cases: an optimal monetary policy under flexible exchange rates, an optimal capital control policy (on households) under fixed exchange rates, and fixed exchange rates (without capital controls). Our Ramsey-type analysis results have shown that although the optimal capital control policy significantly improves welfare under fixed exchange rates, the optimal monetary policy is the most welfare-maximizing in an economy without the financial accelerator.

In the case with the financial accelerator, we compared five cases: an optimal monetary policy under flexible exchange rates, fixed exchange rates (without 
capital controls), an optimal capital control policy on entrepreneurs, an optimal capital control policy on households, and an optimal capital control policy on both entrepreneurs and households under fixed exchange rates. Our results have shown that the optimal monetary policy still outperforms the optimal capital control policy on households. However, the optimal capital control policy on entrepreneurs outperforms the optimal monetary policy. The most welfare-maximizing is the optimal capital control policy on both entrepreneurs and households.

The intuition underlying our analysis results is straightforward. Entrepreneurs finance investment partly with foreign borrowing, which is subject to financial frictions. In an economy with a financial accelerator, the key variable is the foreign interest rate augmented by an external finance premium. Whereas monetary policy works through domestic interest rates, capital controls on entrepreneurs have a direct control on the interest rate at which entrepreneurs borrow from abroad. Hence, capital controls under fixed exchange rates can yield higher welfare in an economy with a financial accelerator coupled with liability dollarization.

As we mention in the introduction, Liu and Spiegel (2015) show that the welfare gain of capital controls depends on the presence of sterilization, and that capital controls and sterilization are complementary policies. Although it is beyond the scope of this study, their findings suggest that if we introduce sterilization into our model, it is highly likely that the welfare gain of capital controls becomes larger. Another useful extension would be to study the role of pecuniary externalities that lead borrowers to overborrow in a small open economy, as examined by Jeanne and Korinek (2010) and Bianchi (2011). If we incorporate the externalities associated with overborrowing into our model, it would magnify the financial-accelerator mechanism effect in an economy. It would be an interesting project to examine 
the role of capital controls in an economy with a larger amplification effect due to pecuniary externalities. We leave these extensions for future research.

\section{Appendix}

In this appendix, we explain the differences between the models with and without entrepreneurs. In the economy without entrepreneurs, households directly make investment and accumulate capital. In this case, the households' budget constraint is given by

$$
\begin{aligned}
P_{t} C_{t}+P_{t} I_{t}+ & \left(1+i_{t-1}\right) A_{t-1}+\left(1+\tau_{h, t-1}\right)\left(1+i_{t-1}^{*}\right) \mathcal{E}_{t} B_{t-1}+P_{t} \frac{\psi_{B}}{2}\left(B_{t}-B\right)^{2} \\
& =A_{t}+\mathcal{E}_{t} B_{t}+W_{t} L_{t}+R_{t}^{K} Q_{t-1} K_{t}+T_{h, t}+\Pi_{t}^{F}
\end{aligned}
$$

Therefore, the optimal conditions associated with households' problem include the following equation:

$$
1=\beta E_{t}\left\{\frac{\lambda_{t+1}^{h}}{\lambda_{t}^{h}} R_{t+1}^{K} \frac{P_{t}}{P_{t+1}}\right\}
$$

where $R_{t}^{K}$ now denotes the return on capital for households.

Since there is no entrepreneurs in this economy, we omit the optimal conditions associated with entrepreneurs' problem (38)-(41). The equilibrium of the economy without entrepreneurs is therefore characterized by a set of stationary stochastic processes $\left\{C_{t}, L_{t}, B_{t}, \Pi_{t}, S_{t}, \frac{P_{t}}{P_{H, t}}, \Pi_{H, t}, q_{t}, Y_{t}, M C_{t}, K_{t}, I_{t}, \frac{Q_{t}}{P_{H, t}}, \tilde{P}_{H, t}, R_{t}^{K}, \frac{R_{t}}{P_{t}}\right.$, $\left.\frac{W_{t}}{P_{t}}, X_{t}^{1}, X_{t}^{2}, \theta_{t}, i_{t}, \mathcal{E}_{t}\right\}_{t=0}^{\infty}$ satisfying Eqs. (11)-(14), (17)-(20), (22)-(24), (29), (35)-(37), (42), (47), (50), (51), (A1), and (A2) (combined with the equations for other variables), given initial values for $B_{-1}$, and $K_{0}$, and exogenous stochastic processes $Z_{t}, E X_{t}$, and $i_{t}^{*}$. 
In the peg case without capital controls (i.e, $\mathcal{E}_{t}=\overline{\mathcal{E}}$, and $\tau_{h}=0$ for all $t$ ), we have 21 endogenous variables and the same number of conditions. In the peg case with the optimal capital control policy, we include $\tau_{t}^{h}$ in the endogenous variables and obtain the Ramsey capital control policy by letting $\tau_{t}^{h}$ be a policy instrument. In the flexible exchange rate case in which $\mathcal{E}_{t}$ is included in the endogenous variables, we let $i_{t}$ be a policy instrument and obtain the Ramsey monetary policy. 


\section{References}

Adjemian, Stéphane, Houtan Bastani, Michel Juillard, Frédéric Karamé, Ferhat Mihoubi, George Perendia, Johannes Pfeifer, Marco Ratto, and Sébastien Villemot (2011) "Dynare: Reference Manual, Version 4," Dynare Working Papers 1, CEPREMAP.

Agénor, Pierre-Richard and Pengfei Jia (2015) "Capital Controls and Welfare with Cross-Border Bank Capital Flows," Centre for Growth and Business Cycle Research Discussion Paper Series 212, Economics, The University of Manchester.

Ahmed, Shaghil and Andrei Zlate (2014) "Capital flows to emerging market economies: A brave new world?" Journal of International Money and Finance, Vol. 48, Part B, pp. 221 - 248.

Benigno, Gianluca, Huigang Chen, Christopher Otrok, Alessandro Rebucci, and Eric R. Young (2013) "Financial Crises and Macro-prudential Policies," Journal of International Economics, Vol. 89, No. 2, pp. 453 - 470.

Bernanke, Ben S., Mark Gertler, and Simon Gilchrist (1999) "The Financial Accelerator in a Quantitative Business Cycle Framework," in Taylor, J. B. and M. Woodford eds. Handbook of Macroeconomics, Vol. 1 of Handbook of Macroeconomics: Elsevier, Chap. 21, pp. 1341-1393.

Bianchi, Javier (2011) "Overborrowing and Systemic Externalities in the Business Cycle," American Economic Review, Vol. 101, No. 7, pp. 3400-3426.

Brunnermeier, Markus K. and Yuliy Sannikov (2014) "International Credit Flows 
and Pecuniary Externalities," Working Paper 20803, National Bureau of Economic Research.

Calvo, Guillermo A. (1983) "Staggered Prices in a Utility-Maximizing Framework," Journal of Monetary Economics, Vol. 12, No. 3, pp. 383-398.

Cespedes, Luis Felipe, Roberto Chang, and Andres Velasco (2000) "Balance Sheets and Exchange Rate Policy," Working Paper 7840, National Bureau of Economic Research.

Céspedes, Luis Felipe, Roberto Chang, and Andrés Velasco (2004) "Balance Sheets and Exchange Rate Policy," American Economic Review, Vol. 94, No. 4, pp. 1183-1193.

Chang, Chun, Zheng Liu, and Mark M. Spiegel (2015) "Capital Controls and Optimal Chinese Monetary Policy," Journal of Monetary Economics, Vol. 74, pp. $1-15$.

Christensen, Ian and Ali Dib (2008) "The financial accelerator in an estimated New Keynesian model," Review of Economic Dynamics, Vol. 11, No. 1, pp. 155-178.

Christiano, Lawrence J., Martin Eichenbaum, and Charles L. Evans (2005) "Nominal Rigidities and the Dynamic Effects of a Shock to Monetary Policy," Journal of Political Economy, Vol. 113, No. 1, pp. 1-45.

Cook, David (2004) "Monetary Policy in Emerging Markets: Can Liability Dollarization Explain Contractionary Devaluations?" Journal of Monetary Economics, Vol. 51, No. 6, pp. 1155-1181. 
Davis, Scott and Ignacio Presno (2014) "Capital Controls as an Instrument of Monetary Policy," Working Paper 171, Federal Reserve Bank of Dallas, Globalization and Monetary Policy Institute.

De Paoli, Bianca and Anna Lipinska (2013) "Capital Controls: a Normative Analysis," staff reports, Federal Reserve Bank of New York.

Devereux, Michael B., Philip R. Lane, and Juanyi Xu (2006) "Exchange Rates and Monetary Policy in Emerging Market Economies," The Economic Journal, Vol. 116, No. 511, pp. 478-506.

Eichengreen, Barry and Ricardo Hausmann (1999) "Exchange Rates and Financial Fragility," Working Paper 7418, National Bureau of Economic Research.

Eichengreen, Barry and Ricardo Hausmann eds. (2005) Other People's Money: University of Chicago Press.

Elekdağ, Selim and Ivan Tchakarov (2007) "Balance Sheets, Exchange Rate Policy, and Welfare," Journal of Economic Dynamics and Control, Vol. 31, No. 12, pp. 3986-4015.

Faia, Ester and Tommaso Monacelli (2005) "Optimal Monetary Policy Rules, Asset Prices and Credit Frictions," working papers, IGIER,Bocconi University. (2008) "Optimal Monetary Policy in a Small Open Economy with Home Bias," Journal of Money, Credit and Banking, Vol. 40, No. 4, pp. 721-750.

Farhi, Emmanuel and Ivan Werning (2012) "Dealing with the Trilemma: Optimal Capital Controls with Fixed Exchange Rates," Working Paper 18199, National Bureau of Economic Research. 
Forbes, Kristin, Marcel Fratzscher, Thomas Kostka, and Roland Straub (2016) "Bubble thy neighbour: Portfolio effects and externalities from capital controls," Journal of International Economics, Vol. 99, pp. 85 - 104.

Galí, Jordi and Tommaso Monacelli (2005) "Monetary Policy and Exchange Rate Volatility in a Small Open Economy," The Review of Economic Studies, Vol. 72, No. 3, pp. 707-734.

Ghosh, Atish R., Jonathan David Ostry, and Mahvash S Qureshi (2017) "Managing the Tide; How Do Emerging Markets Respond to Capital Flows?," IMF Working Papers 17/69, International Monetary Fund.

Jeanne, Olivier, Arvind Subramanian, and John Williamson (2012) Who Needs to Open the Capital Account?: Peterson Institute for International Economics.

Jeanne, Olivier and Anton Korinek (2010) "Excessive Volatility in Capital Flows: A Pigouvian Taxation Approach," American Economic Review, Vol. 100, No. 2, pp. $403-07$.

Jongwanich, Juthathip and Archanun Kohpaiboon (2012) "Effectiveness of Capital Controls: Evidence from Thailand," Asian Development Review, Vol. 29, No. 2, pp. 50-93.

Kim, Jinill and Sunghyun Henry Kim (2003) "Spurious Welfare Reversals in International Business Cycle Models," Journal of International Economics, Vol. 60, No. 2, pp. 471-500.

Kitano, Shigeto (2004) "Macroeconomic Effect of Capital Controls as a Safeguard 
Against the Capital Inflow Problem," Journal of International Trade E5 Economic Development, Vol. 13, No. 3, pp. 233-263.

(2011) "Capital Controls and Welfare," Journal of Macroeconomics, Vol. 33, No. 4, pp. 700 - 710.

Kitano, Shigeto and Kenya Takaku (2017a) "Capital Controls and Financial Frictions in a Small Open Economy," Open Economies Review, Vol. 28, No. 4, pp. 761-793.

(2017b) "Capital Controls as a Credit Policy Tool in a Small Open Economy," The B.E. Journal of Macroeconomics, forthcoming.

(2017c) "Capital Controls, Macroprudential Regulation, and the Bank Balance Sheet Channel," Discussion Paper Series DP2017-18, Research Institute for Economics \& Business Administration, Kobe University.

Kiyotaki, Nobuhiro and John Moore (1997) "Credit Cycles," Journal of Political Economy, Vol. 105, No. 2, pp. 211-248.

Kollmann, Robert (2002) "Monetary Policy Rules in the Open Economy: Effects on Welfare and Business Cycles," Journal of Monetary Economics, Vol. 49, No. 5, pp. 989-1015.

Korinek, Anton (2011) "The New Economics of Prudential Capital Controls: A Research Agenda," IMF Economic Review, Vol. 59, No. 3, pp. 523-561.

Levin, Andrew T., Alexei Onatski, John Williams, and Noah M. Williams (2006) "Monetary Policy under Uncertainty in Micro-Founded Macroeconometric Mod- 
els," in Gertler, Mark and Kenneth Rogoff eds. NBER Macroeconomics Annual 2005, Volume 20: MIT Press, pp. 229-312.

Liu, Zheng and Mark M. Spiegel (2015) "Optimal Monetary Policy and Capital Account Restrictions in a Small Open Economy," IMF Economic Review, Vol. 63, No. 2, pp. 298-324.

Merola, Rossana (2010) "Optimal monetary policy in a small open economy with financial frictions," Discussion Paper Series 1: Economic Studies 2010,01, Frankfurt, M.

Neumeyer, Pablo A. and Fabrizio Perri (2005) "Business Cycles in Emerging Economies: The Role of Interest Rates," Journal of Monetary Economics, Vol. 52, No. 2, pp. 345-380, March.

Ostry, Jonathan David, Mahvash Saeed Qureshi, Karl Habermeier, Dennis Bernhard Sebastian Reinhardt, Marcos Chamon, and Atish Ghosh (2010) "Capital Inflows: The Role of Controls," IMF Staff Position Notes 2010/04, International Monetary Fund.

Ostry, Jonathan, Atish Ghosh, and Anton Korinek (2012) "Multilateral Aspects of Managing the Capital Account," IMF Staff Discussion Notes 12/10, International Monetary Fund.

Ravenna, Federico and Fabio M. Natalucci (2008) "Monetary Policy Choices in Emerging Market Economies: The Case of High Productivity Growth," Journal of Money, Credit and Banking, Vol. 40, No. 2-3, pp. 243-271. 
Schmitt-Grohé, Stephanie and Martín Uribe (2003) "Closing Small Open Economy Models," Journal of International Economics, Vol. 61, No. 1, pp. 163-185.

(2004) "Solving Dynamic General Equilibrium Models Using a SecondOrder Approximation to the Policy Function," Journal of Economic Dynamics and Control, Vol. 28, No. 4, pp. 755-775.

(2006) "Optimal Simple and Implementable Monetary and Fiscal Rules: Expanded Version," Working Paper 12402, National Bureau of Economic Research.

(2007) "Optimal Simple and Implementable Monetary and Fiscal Rules," Journal of Monetary Economics, Vol. 54, No. 6, pp. 1702 - 1725.

(2016) "Downward Nominal Wage Rigidity, Currency Pegs, and Involuntary Unemployment," Journal of Political Economy, Vol. 124, No. 5, pp. $1466-1514$. 